Article

\title{
Design and Optimization of a Hyper-Branched Polyimide Proton Exchange Membrane with Ultra-High Methanol-Permeation Resistivity for Direct Methanol Fuel Cells Applications
}

\author{
Liying Ma ${ }^{1}$, Guoxiao $\mathrm{Xu}^{2}$, Shuai $\mathrm{Li}^{2}$, Jiao $\mathrm{Ma}^{1}$, Jing $\mathrm{Li}^{2, *}$ and Weiwei Cai ${ }^{2, *}$ \\ 1 School of Chemistry and Materials Science, Guizhou Normal University, 116 Baoshan North Road, \\ Guiyang 550001, China; maliying2018@163.com (L.M.); Mj68031104@163.com (J.M.) \\ 2 Sustainable Energy Laboratory, Faculty of Materials Science and Chemistry, China University of Geosciences \\ Wuhan, 388 Lumo RD, Wuhan 430074, China; guoxiao_xu123@163.com (G.X.); \\ lishuai19970115@163.com (S.L.) \\ * Correspondence: kinijing1984@gmail.com (J.L.); willcai1985@gmail.com (W.C.); \\ Tel.: +86-188-7116-0686 (J.L. \& W.C.)
}

Received: 25 September 2018; Accepted: 18 October 2018; Published: 22 October 2018

\begin{abstract}
A hyper-branched sulfonated polyimide (s-PI) was synthesized successfully and composited with polyvinylidene fluoride (PVDF) to achieve ultra-high methanol-permeation resistive for direct methanol fuel cell application. The optimized s-PI-PVDF composite membrane exhibited methanol resistivity low to $1.80 \times 10^{-8} \mathrm{~cm}^{2} / \mathrm{s}$, two orders of magnitude lower than the value of the commercial Nafion 117 membrane $\left(60 \times 10^{-7} \mathrm{~cm}^{2} / \mathrm{s}\right)$. At the same time, the tensile strength of the composite membrane is $22 \mathrm{MPa}$, which is comparable to the value of the Nafion 117 membrane. Therefore, the composite membrane is promising for application in direct methanol fuel cell.
\end{abstract}

Keywords: proton exchange membrane; direct methanol fuel cell; methanol resistivity; composite membrane

\section{Introduction}

Recently, polymer exchange membrane fuel cells (PEMFCs) have attached increasing attention for applications such as low-emission vehicles, stationary power and portable electronics [1,2]. The key component of PEMFC is the proton exchange membrane (PEM), which conduct protons and separate the fuel from oxidant. The important role of an efficient PEM contain high proton conductivity, good mechanical, chemical, thermal and dimensional stability, and low fuel permeability [3-6]. A polyperfluorosulfonic acid proton membrane nafion (Dupont) is the most widely used PEM in PEMFCs due to the high proton conductivity and good chemical stability $[7,8]$. However, the high cost and especially the serious methanol permeation of Nafion hinder the potential application in Direct Methanol Fuel Cells (DMFCs) [9,10]. As an alternative to Nafion, partially fluorinated [11-17] and non-fluorinated PEMs [18-29] have been widely developed.

Among many advanced sulfonated PEMs, such as poly (ether ether ketone) (PEEK) [30,31], poly (ether ketone) [32], polyamide [33-37], poly (arylene ether) [38,39] and polyimide [2,40,41], sulfonated polyimide is considered one of the most potential alternative PEM to be used in fuel cells [41]. Watanabe et al. [40] synthesized several sulfonated polyimide copolymers and showed good oxidative stability, mechanical strength and proton conductivity. Ding et al. [41] prepared a series of sulfonated polyimides proton exchange membranes; the membranes exhibit acceptable proton conductivity and low methanol permeability. 
In this study, we designed and synthesized a hyper-branched non-fluorinated sulfonated polyimide (s-PI) based composite PEM to overcome the methanol crossover issue. In order to enhance the mechanical strength of the PEMs, polyvinylidene fluoride (PVDF) was used as a binder due to the great mechanical stability and high flexibility [42]. Structural and thermodynamic compatibility, which was proved to be of great importance to the quality of the blend membrane [43-45], between PVDF and PI has been proved [46]. The main properties of the PEMs, including the proton conductivity, methanol permeability and mechanical/thermal property, thermal stabilities were systematically investigated. The optimized PEM exhibits a methanol permeability that is low to $1.9 \times 10^{-8} \mathrm{~cm}^{2} / \mathrm{s}$, more than two orders of magnitude lower than that of the commercial Nafion 117 membrane [47]. In addition, the tensile stress of the optimized PEM is as high as $22 \mathrm{MPa}$. The overall performances suggest that the $s$-PI based composite PEM has the potential of application in DMFC.

\section{Experimental}

\subsection{Materials}

Phloroglucinol (PL), 4-nitrophthalontrile (NPN), 2,4-diaminobenzenesulfonic acid (DSA), m-cresol and polyvinylidene fluoride (PVDF) were provided by Sigma-Aldrich Reagent, Ltd. (St. Louis, MO, USA), and dried for $24 \mathrm{~h}$ at $80{ }^{\circ} \mathrm{C}$ before using. Dimethyl sulfoxide (DMF), $\left(\mathrm{CH}_{2} \mathrm{OH}\right)_{2}, \mathrm{~K}_{2} \mathrm{CO}_{3}, \mathrm{KOH}$ and HAc were purchased from Sinopharm Chemical Reagent Co., Ltd. (Chengdu, China)

\subsection{Synthesis}

Synthesis of product a: PL (10 mmol), NPN (30 mol), $\mathrm{K}_{2} \mathrm{CO}_{3}(8.28 \mathrm{~g})$, and DMF $(60 \mathrm{~mL})$ were added in to a $100 \mathrm{~mL}$ two-necked round-bottom flask, the reaction was maintained $25^{\circ} \mathrm{C}$ for $48 \mathrm{~h}$ under argon atmosphere. Upon completion, the mixture was poured into $500 \mathrm{~mL}$ water, filtered and washed with water, and then dried at $80{ }^{\circ} \mathrm{C}$ for $24 \mathrm{~h}$ (Scheme 1).

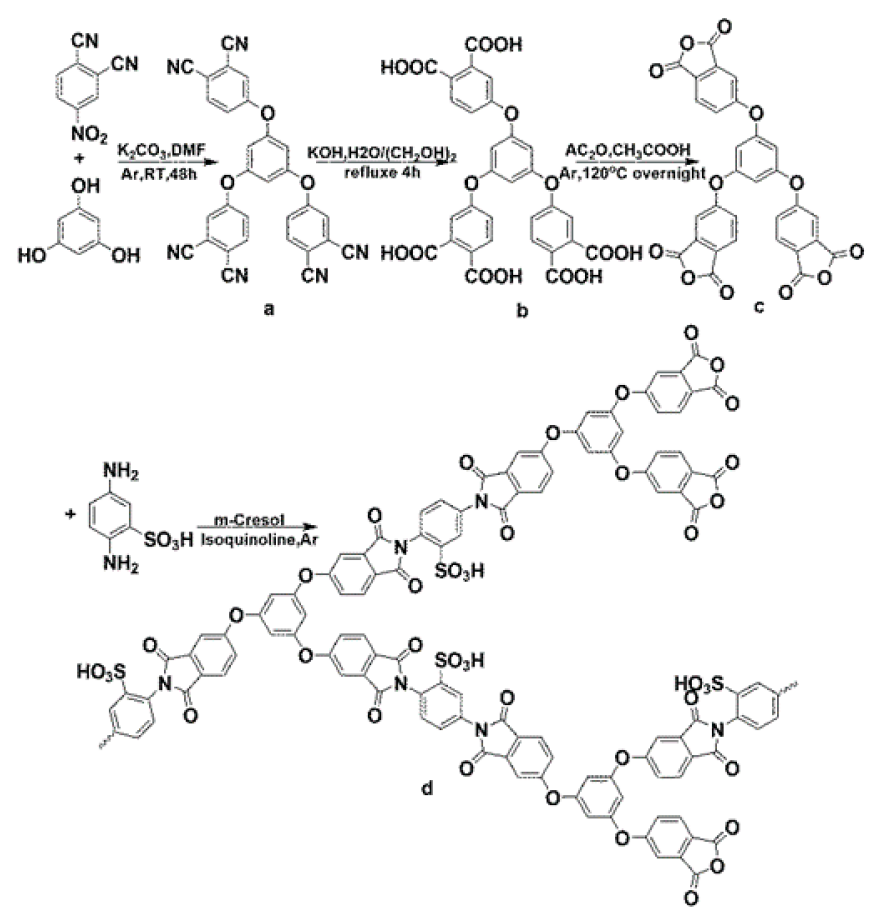

Scheme 1. Route of polymer synthesis.

Synthesis of product b: Product a $(4.5 \mathrm{mmol}), \mathrm{KOH}(2.77 \mathrm{~g}), \mathrm{H}_{2} \mathrm{O}(12 \mathrm{~mL})$ and $\left(\mathrm{CH}_{2} \mathrm{OH}\right)_{2}(12 \mathrm{~mL})$ were added into a $100 \mathrm{~mL}$ round-bottom flask, the mixture was kept stirred at $115^{\circ} \mathrm{C}$ for $4 \mathrm{~h}$ under 
argon atmosphere. After cooling to RT, the resulting solution was filtered and washed with water several times, and the white crystal was dried at $80^{\circ} \mathrm{C}$ for $24 \mathrm{~h}$ (Scheme 1).

Synthesis of product c: Product b $(2 \mathrm{mmol}), \mathrm{HAc}(20 \mathrm{~mL}), \mathrm{Ac}_{2} \mathrm{O}(2 \mathrm{~mL})$ were added in to $50 \mathrm{~mL}$ round-bottom flask, the reaction was maintained at $120^{\circ} \mathrm{C}$ overnight. After the reaction was completed, the resulting solution was cooled to RT, then filtered and washed with cold water. The white products were dried under vacuum at $80^{\circ} \mathrm{C}$ for $24 \mathrm{~h}$ (Scheme 1).

Synthesis of polymer s-PI (d): Product c ( $5 \mathrm{mmol})$, DSA ( $5 \mathrm{mmol}), \mathrm{m}$-cresol $(5 \mathrm{~mL})$ and isoquinoline $(0.2 \mathrm{~mL})$ were added in to a $50 \mathrm{~mL}$ round-bottom flask, the reaction was kept stirred at $100{ }^{\circ} \mathrm{C}$ for $5 \mathrm{~h}$ under argon atmosphere and then rose to $120^{\circ} \mathrm{C}$ overnight. The solution was poured into $50 \mathrm{~mL}$ methanol, then filtered and washed with methanol, and dried at $80{ }^{\circ} \mathrm{C}$ for $24 \mathrm{~h}$ under vacuum (Scheme 1).

\subsection{Membrane Preparation}

The membranes were fabricated via a solution casting technique. The hybrid homogeneous solution of polymer and PVDF in dimethyl sulfoxide (DMSO) were filtered and cast on clean glass plates and dried at $80^{\circ} \mathrm{C}$. All the dried membranes were treated in $1 \mathrm{M} \mathrm{HCl}$ solution for $12 \mathrm{~h}$ at room temperature, and then washed with deionized water several times until the $\mathrm{pH}=7$.

\subsection{Measurements and Characterizations}

${ }^{1} \mathrm{H}$ nuclear magnetic resonance (NMR) spectra of the synthesized products and polymer were recorded using a Bruker AVANCE IIIHD instrument (400 MHz, Bruker, Hamburg, Germany) in deuterated dimethyl sulfoxide $\left(\right.$ DMSO- $\mathrm{d}_{6}$ ) as solvent. The FTIR spectra of synthesized products and polymer were conducted on a FTIR Nicolet6700 spectrometer (Thermo Fisher Scientific, Waltham, MA, USA). Thermogravimetric (TG) analysis of the composite membranes was recorded on a NETZSCH simultaneous thermal analyzer (Netzsch, Bavaria, Germany) at $10{ }^{\circ} \mathrm{C} / \mathrm{min}$ ramping up to $600^{\circ} \mathrm{C}$ under a nitrogen atmosphere. Cross-section morphologies of the composite membranes were obtained from a field emission scanning electron microscopy (SEM, SU8010, Hitachi, Tokyo, Japan). Proton conductivity was measured by four-electrode AC impendence method with Interface 1000 electrochemical workstation (Gamry, Philadelphia, PA, USA). Proton conductivity was measured under the temperature from 25 to $80{ }^{\circ} \mathrm{C}$ with a relative humidity of $\mathrm{RH}=100 \%$. Proton conductivity was calculated using the following Equation:

$$
\sigma=\frac{d}{R t w}
$$

where $\sigma$ is the proton conductivity of the membranes $(\mathrm{S} / \mathrm{cm}), w$ and $t$ refer to the width $(\mathrm{cm})$ and thickness $(\mathrm{cm})$ of the membrane, respectively. $d$ stands for the distance between the two electrodes $(\mathrm{cm}) . R$ is the resistance of the measured impedance data $(\Omega)$.

The methanol permeability of composite membranes was carried out via an " $\mathrm{H}$ " type diaphragm diffusion cell. One diffusion cell contained $10.0 \mathrm{M}$ methanol solution and the other sampling cell contained the same volume of deionized water, which was separated by the membrane and stirred with magnetic stirrer for diffusion. The concentration of methanol in the sampling cell was measured via a gas chromatograph (9790II, Zhejiang Fuli Analytical Instruments Co., Ltd., Wenling, China). The methanol permeability was calculated according to the Equation as follows:

$$
p=\frac{l}{A} \times \frac{V_{B}}{C_{A}} \times \frac{\Delta C}{\Delta t}
$$

where $p$ is the methanol permeability $\left(\mathrm{cm}^{2} / \mathrm{s}\right), C_{A}$ is the initial concentration of methanol $\left(\mathrm{mol} / \mathrm{cm}^{3}\right)$, $V_{\mathrm{B}}$ is the volume of the compartment $\left(\mathrm{cm}^{3}\right), A$ and $l$ are the effective diffusion area and the thickness, respectively. $\Delta t$ and $\Delta C$ are diffusion time (s) and methanol concentration $\left(\mathrm{mol} / \mathrm{cm}^{3}\right)$, respectively. 
Ion exchange capacity (IEC) of the composite membranes was measured through the classical acid-base titration method. Dried membrane was first immersed in $1 \mathrm{M} \mathrm{NaCl}$ solution for $48 \mathrm{~h}$ at room temperature to replace the $\mathrm{H}^{+}$ions with $\mathrm{Na}^{+}$ions, and then the content of exchange proton $\mathrm{H}^{+}$ was titrated with $0.01 \mathrm{M} \mathrm{NaOH}$ solution using phenolphthalein as an indicator. The IEC value was calculated according to the following Equation:

$$
I E C=\frac{V \times C}{W}(\mathrm{mmol} / \mathrm{g})
$$

where $V$ and $C$ represent for the volume $(\mathrm{mL})$ and the concentration $(\mathrm{mol} / \mathrm{L})$ of $\mathrm{NaOH}$ solution, respectively. $W$ stands for the weight of dry membrane $(\mathrm{g})$.

Water uptake and volume swelling were tested according to the following process. A piece of composite membrane sample was first placed in ultrapure water for $12 \mathrm{~h}$ at an ambient temperature, then the weight and the volume were immediately recorded upon removal of the surface water with tissue paper. The membrane was dried at $80^{\circ} \mathrm{C}$ for $12 \mathrm{~h}$ under vacuum to remove the residual water to measure the volume and the weight quickly. Water uptake $(W U)$ and volume swelling $(V S)$ were obtained using the below Equation, respectively:

$$
W U=\frac{\left(W_{\mathrm{Wet}}-W_{\mathrm{dry}}\right)}{W_{\mathrm{dry}}} \times 100 \%
$$

where $W_{\text {wet }}$ and $W_{\text {dry }}$ are the weight of wet and dry membranes, respectively.

$$
V S=\frac{V_{\text {Wet }}-V_{\text {dry }}}{V_{\text {dry }}} \times 100 \%
$$

where $V_{\text {wet }}$ and $V_{\text {dry }}$ are corresponding to the volume of the wet and dry membranes, respectively.

The tensile stress and elongation at break of a rectangular composite membrane samples was measured using Labthink XLW (PC) (Labthink, Jinan, China) with a $50 \mathrm{~N}$ load cell at a tensile speed of $25 \mathrm{~mm} / \mathrm{min}$ at ambient temperature.

\section{Results and Discussion}

Figure 1 displays the ${ }^{1} \mathrm{H}$ NMR spectra of the intermediate products and the s-PI polymer. For the intermediate product a, ${ }^{1} \mathrm{H} \mathrm{NMR}\left(400 \mathrm{MHz}, \mathrm{DMSO}-\mathrm{d}_{6}\right)$, the distinct resonances at $8.2,8.0$ and $7.6 \mathrm{ppm}$ present the phenyl group with $-\mathrm{CN}$ group. The signal at $7.1 \mathrm{ppm}$ is attributed to the phenyl group. For the product $\mathrm{b},{ }^{1} \mathrm{H}$ NMR (400 MHz, DMSO- $\mathrm{d}_{6}$ ), the distinct resonances at 7.8, 7.3 and 7.1 ppm ascribe to the hydrogen atom of the phenyl group with $-\mathrm{COOH}$ group. The signal at $6.6 \mathrm{ppm}$ is attributed to the phenyl group inside. For precursor $\mathrm{c}^{1}{ }^{1} \mathrm{H}$ NMR $\left(400 \mathrm{MHz}, \mathrm{DMSO}-\mathrm{d}_{6}\right)$, the distinct resonances at 8.1, 7.8 and $7.7 \mathrm{ppm}$ ascribe to the three phenyl group outside, while the signal at $6.9 \mathrm{ppm}$ is assigned to the phenyl group inside. For polymer, the signals at $11.5 \mathrm{ppm}$ presented the $-\mathrm{SO}_{3} \mathrm{H}$ of polymer. 

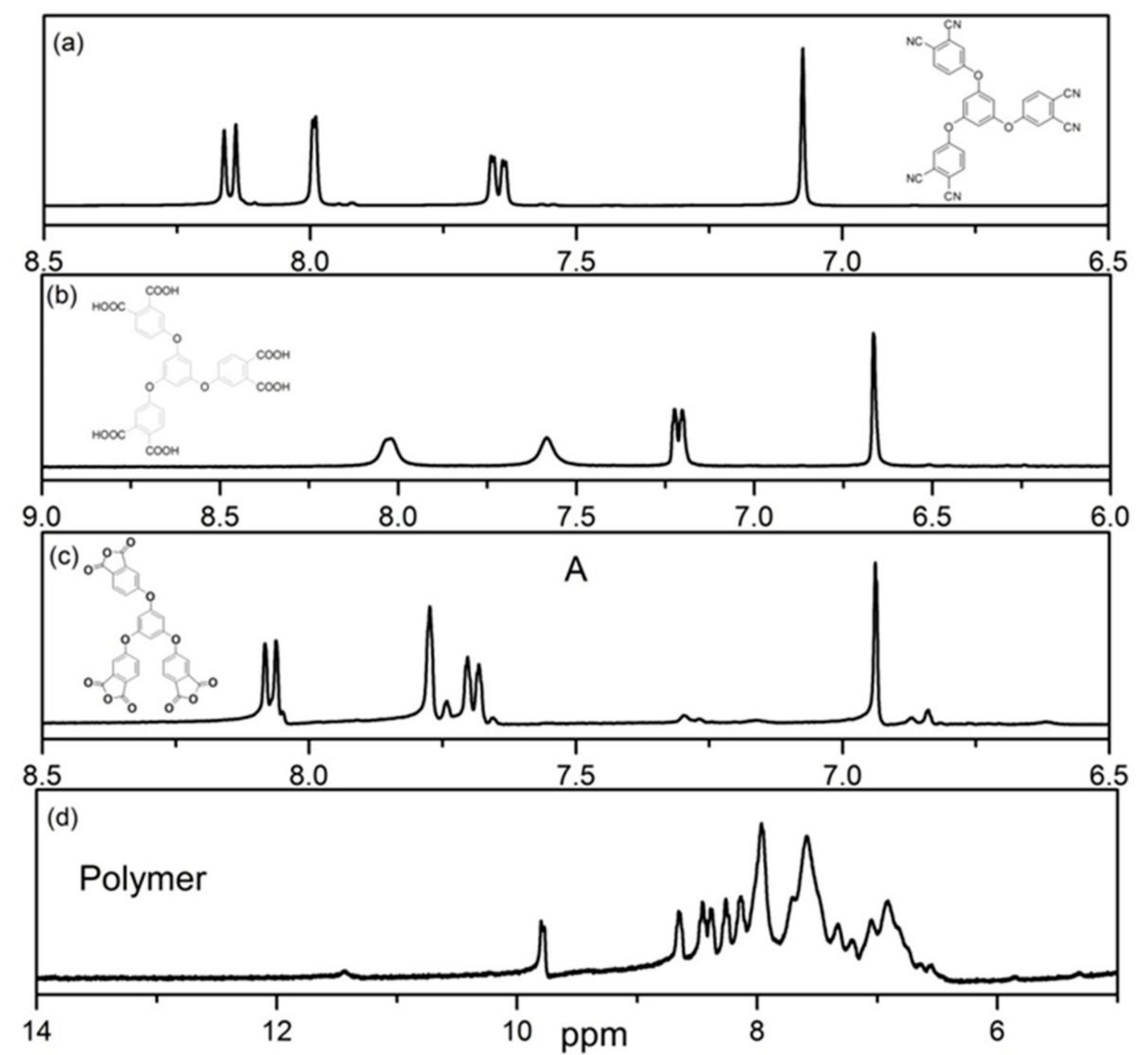

Figure 1. ${ }^{1} \mathrm{H}$ NMR spectra of the intermediate product $(\mathbf{a}-\mathbf{c})$ and the sulfonated polyimide (s-PI) polymer (d).

In addition to ${ }^{1} \mathrm{H} \mathrm{NMR}$, successful synthesis of the intermediate products and the s-PI polymer was confirmed by FTIR spectra provided in Figure 2. For the intermediate product a, the FTIR spectrum depicts the $\mathrm{C} \equiv \mathrm{N}$ stretching bands at about 2230 and $1600 \mathrm{~cm}^{-1}$. For intermediate product $\mathrm{b}, 3500-3200$ $\mathrm{cm}^{-1}\left(v_{\mathrm{OH}},-\mathrm{COOH}\right), 1600 \mathrm{~cm}^{-1}\left(v_{\mathrm{C}=\mathrm{O}},-\mathrm{COOH}\right)$. For product $\mathrm{c}$, the bands at 1850 and $1770 \mathrm{~cm}^{-1}$ indicate the presence of the $\mathrm{C}=\mathrm{O}$ stretching vibration, and the band at $1260 \mathrm{~cm}^{-1}$ reflects the $\mathrm{C}-\mathrm{O}$ stretching vibration of cyclic anhydride. For polymer, the peak at 1730 and $1600 \mathrm{~cm}^{-1}$ confirms the presence of the $\mathrm{C}=\mathrm{O}$ stretching of the anhydride group, the bands of 1360 and $1232 \mathrm{~cm}^{-1}$ reflects the $\mathrm{C}=\mathrm{O}$ stretching of the carboxylic group. The bands at $1120 \mathrm{~cm}^{-1}$ ascribed to the $-\mathrm{SO}_{3} \mathrm{H}$ group.

The methanol permeation property of a PEM is the key factor when considering the DMFC application. Methanol permeability through the s-PI-PVDF composite membranes was depicted in Figure 3. The composite membrane described methanol permeability in the range of $1.80 \times 10^{-8} \mathrm{~cm}^{2} / \mathrm{s}$ to $2.80 \times 10^{-8} \mathrm{~cm}^{2} / \mathrm{s}$, much lower than that through the Nafion 117 membrane $\left(60 \times 10^{-7} \mathrm{~cm}^{2} / \mathrm{s}\right)$ [47] . Apparently, with the PVDF weight ratio increasing from 30\% to $60 \%$, the methanol permeability value is remarkably depressed. The ultra-low methanol permeability of all the four composite membranes can also be illustrated by the flat and uniform topography SEM image of the smooth cross-section surface, as shown in Figure 4.

As one of the most important properties of any PEM, proton conductivities of the composite membranes measured at different temperatures are displayed in Figure 5. Membranes with higher s-PI polymer content exhibit higher conductivity due to the higher concentration of proton in the membrane contributed from the acidic sulfonamide groups while PVDF is inert on proton conduction. At the same time, proton conductivity increases with the increased temperature for all the measured membranes due to the depended of proton mobility on temperature. Unfortunately, the proton conductivity of the composite membranes is still much lower than that of the Nafion $117\left(80^{\circ} \mathrm{C}, 0.19 \mathrm{~S} / \mathrm{cm}\right)$. It can be 
found that with $30 \%$ PVDF hybrid, the composite membrane exhibited the best proton conductive property among the four membranes. The trend of proton conductivity also agrees with that of the measured IEC value of the membranes as listed in Table 1 . With the s-PI polymer content in membrane increased from $40 \%$ to $70 \%$, IEC value of the composite membranes increased from 0.35 to $0.62 \mathrm{mmol} / \mathrm{g}$, which is also much lower than that of the Nafion 117 membrane.

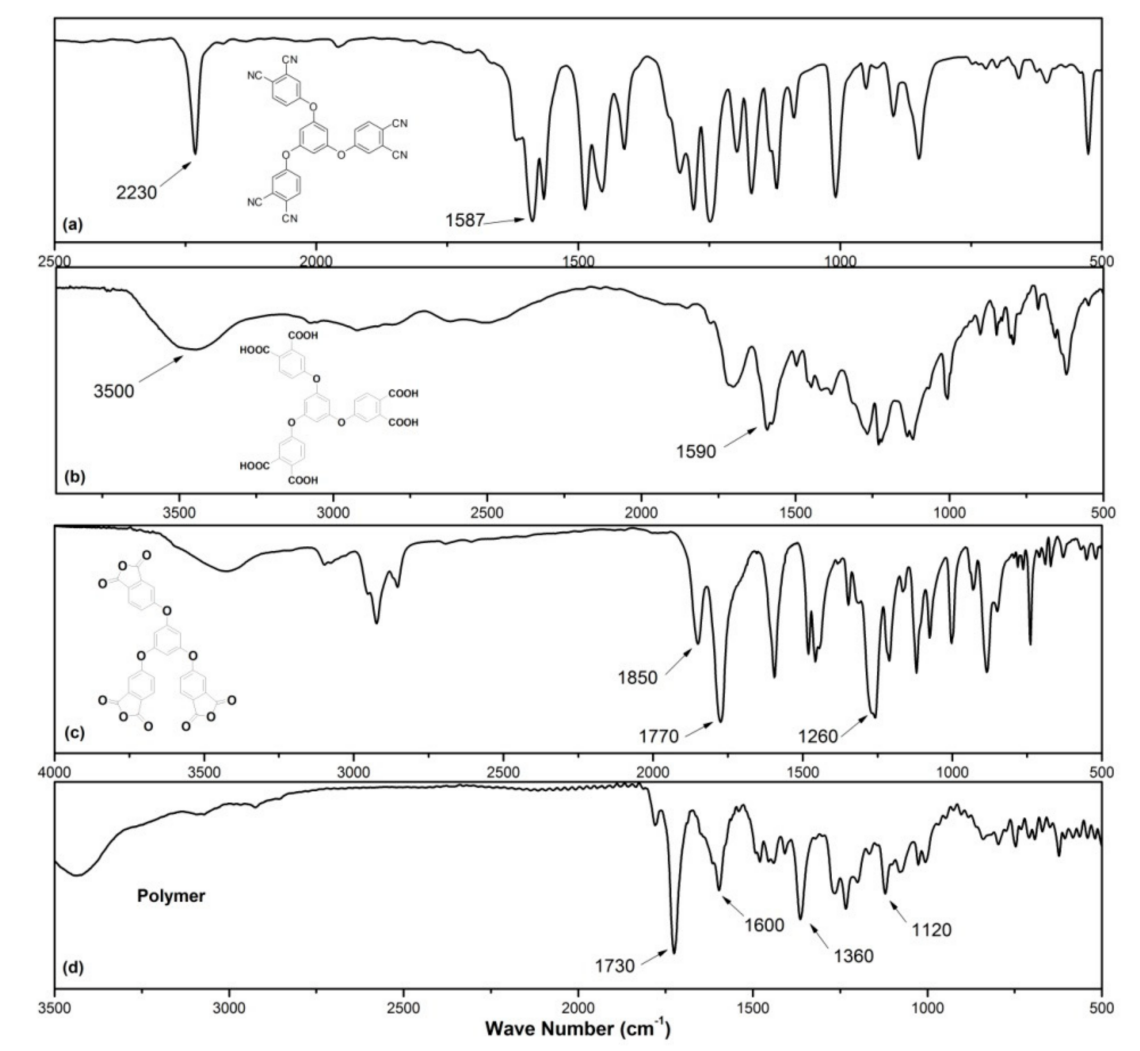

Figure 2. FTIR spectra of the product $(\mathbf{a}-\mathbf{c})$ and s-PI polymer $(\mathbf{d})$.

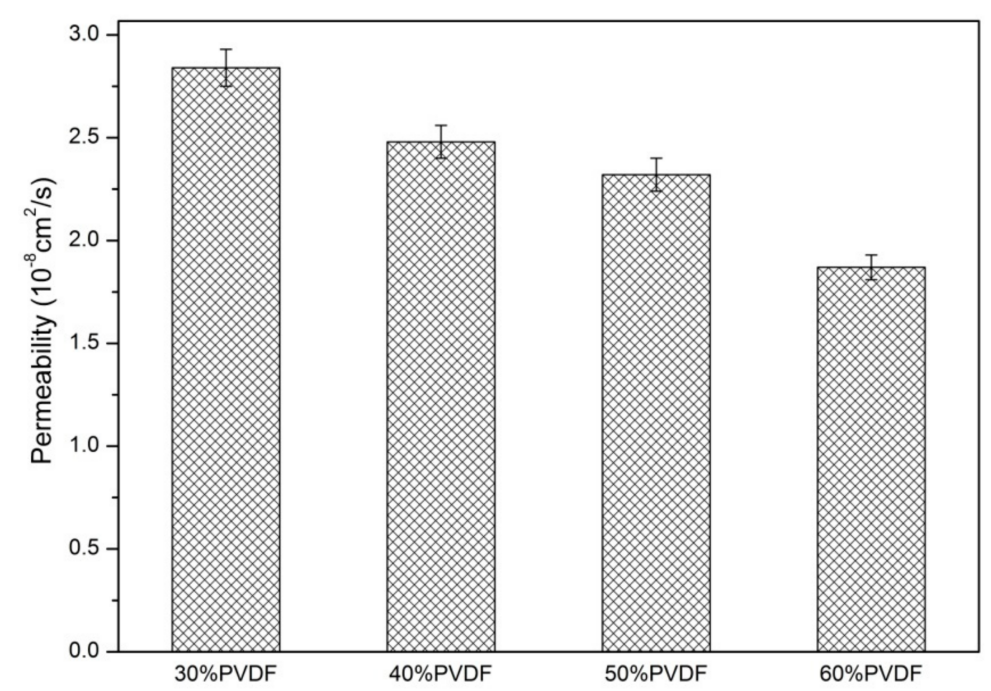

Figure 3. Methanol permeability through the s-PI-polyvinylidene fluoride (PVDF) composite membranes. 


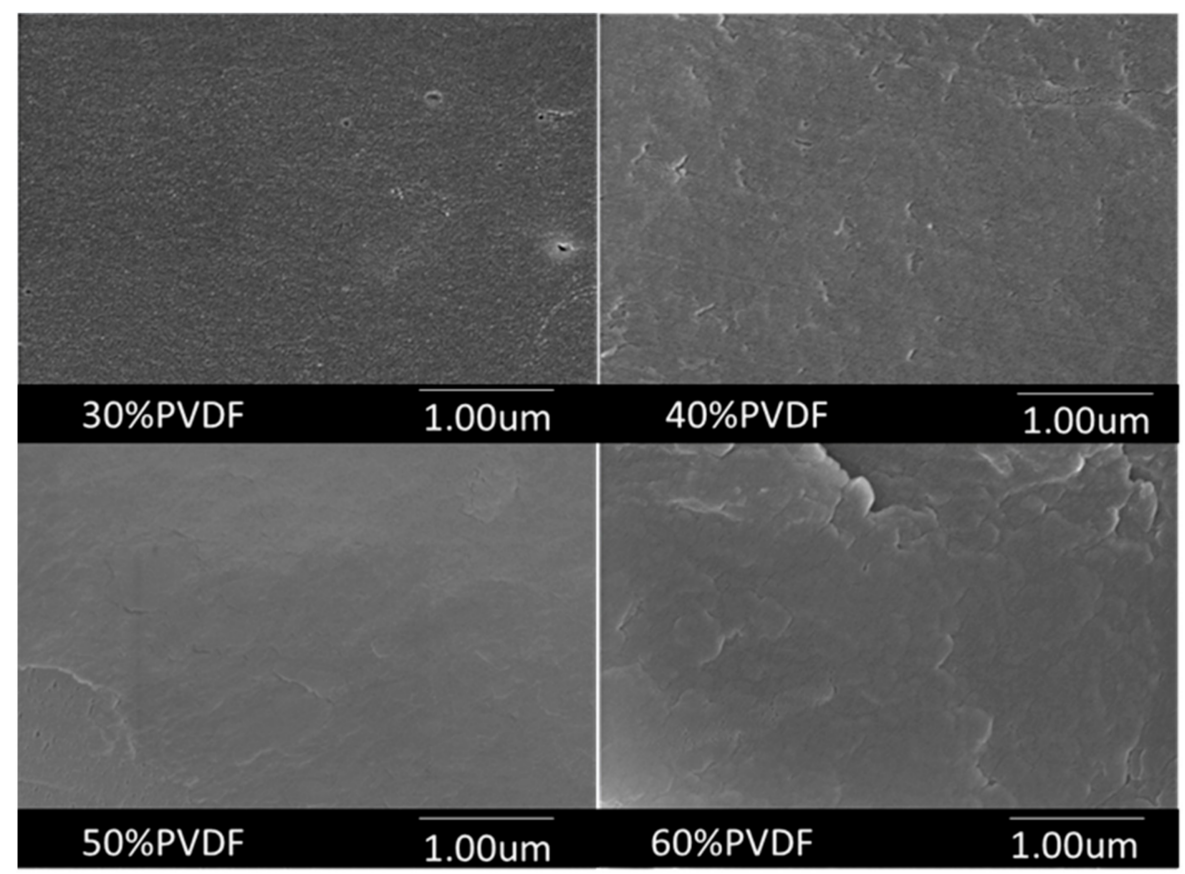

Figure 4. The cross-section SEM images of the s-PI-PVDF composite membranes.

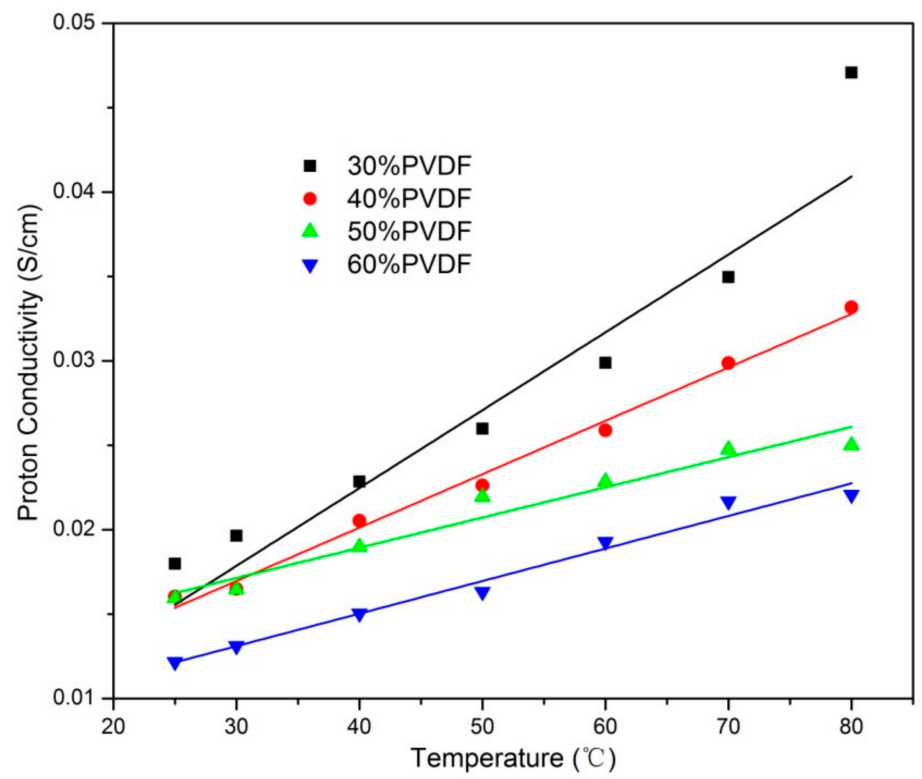

Figure 5. Temperature dependences of proton conductivity of the s-PI-PVDF composite membranes.

Table 1. Water uptake, volume swelling and ion exchange capacity (IEC) of s-PI-PVDF composite membranes and Nafion 117.

\begin{tabular}{cccccc}
\hline Membranes & $\mathbf{3 0} \%$ PVDF & 40\% PVDF & $\mathbf{5 0 \%}$ PVDF & $\mathbf{6 0 \%}$ PVDF & Nafion 117 \\
\hline Water uptake (\%) & $25.79 \pm 0.03$ & $17.87 \pm 0.04$ & $14.11 \pm 0.04$ & $9.05 \pm 0.03$ & $20.97 \pm 0.05$ \\
Volume swelling (\%) & $26.95 \pm 0.05$ & $25.84 \pm 0.06$ & $24.73 \pm 0.04$ & $14.87 \pm 0.04$ & $36.29 \pm 0.05$ \\
IEC (mmol/g) & $0.6212 \pm 0.03$ & $0.5931 \pm 0.02$ & $0.5719 \pm 0.03$ & $0.3540 \pm 0.04$ & $0.91 \pm 0.05$ \\
\hline
\end{tabular}

To evaluate the overall performance of the s-PI-PVDF composite membrane for DMFC application, the selectivity $s=\sigma / p$, where $\sigma$ is the proton conductivity and $p$ is the methanol permeability, of the $s$-PI-PVDF membranes were calculated as compared in Figure 6. It can be found that the membrane with $30 \%$ PVDF content exhibited the greatest selectivity of higher than $7 \times 10^{5} \mathrm{Ss} / \mathrm{cm}^{3}$. As a 
result, $30 \%$ is considered as the optimal PVDF content in the s-PI-PVDF composite membrane for DMFC application.

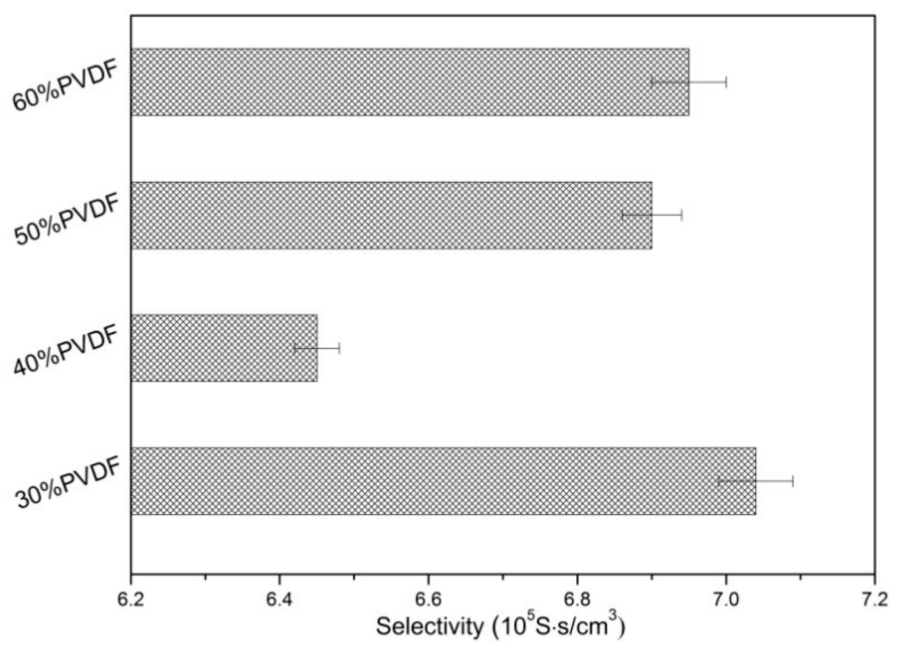

Figure 6. Selectivity of the s-PI-PVDF composite membranes.

Water retention capacity of the PEM is one of the key factors due to water serves as the proton carrier during proton transporting according to vehicle mechanism $[32,48]$ while excessive water would diminish the mechanical stability of the membrane [49]. The water uptake and volume swelling ratio of the s-PI-PVDF composite membranes were measured and are depicted in Table 1. All of the s-PI-PVDF composite membranes exhibit lower water uptake and volume swelling than that of Nafion 117 do. It verifies that the s-PI-PVDF composite membrane expresses much lower methanol permeability than that of the Nafion 117, due to the high water uptake commonly leading to the generation of methanol crossover channels.

Mechanical stability and thermal stability of the s-PI-PVDF composite membranes were subsequently analyzed for the consideration of long-term application in DMFC [50]. The mechanical strengths of the composite membranes are shown in Figure 7a. Clearly, all the curves show the same profile, the initial linear was typical elastic response, then the curve was the inelastic response before the yield point, and finally the curve is attained at the maximum strength at break [51-53]. The tensile strength of the composite membranes increases with the PVDF content in the composite membranes. The $60 \%$ PVDF membrane exhibits the best tensile strength (22 MPa), and the $30 \%$ PVDF membrane is the lowest of $17 \mathrm{MPa}$ among the four composite membranes, which is comparable to that of Nafion 117 membrane (20 MPa) and might adequate for fuel cell operation application [54]. The typical thermal stability of the s-PI-PVDF composite membranes was collected under nitrogen atmosphere. The TG curves of the composite membranes are plotted in Figure $7 \mathrm{~b}$. The composite membranes show three-step weight loss thermograms in the curve analysis and can be comparable to the analogue aromatic s-PI [41]. The slight weight loss at about $170{ }^{\circ} \mathrm{C}$ was attributed to the evaporation of absorbed solvent and water. The second weight loss at about $400{ }^{\circ} \mathrm{C}$ was caused by the degradation of the sulfonic groups from the membrane. The degradation at about $500{ }^{\circ} \mathrm{C}$ is due to the decomposition of the main chain itself. The $5 \%$ mass loss temperature of the membrane is higher than $220{ }^{\circ} \mathrm{C}$. In conclusion, the mechanical and thermal properties of the four s-PI-PVDF composite membranes are satisfied for DMFC applications. It can be concluded from the mechanical and thermal stability comparisons that the stability of the s-PI-PVDF composite membrane is strongly related to the PVDF content in the membrane. Enough PVDF in the membrane can provided continuous PVDF network for mechanical stability consideration and protection on the fragile segment of the s-PI polymer. Above all, all of the prepared s-PI-PVDF composite membranes meet the stability requirement of PEMs for applications in DMFCs $\left(\sim 80^{\circ} \mathrm{C}\right)$ [2] and displays good thermal stability. 

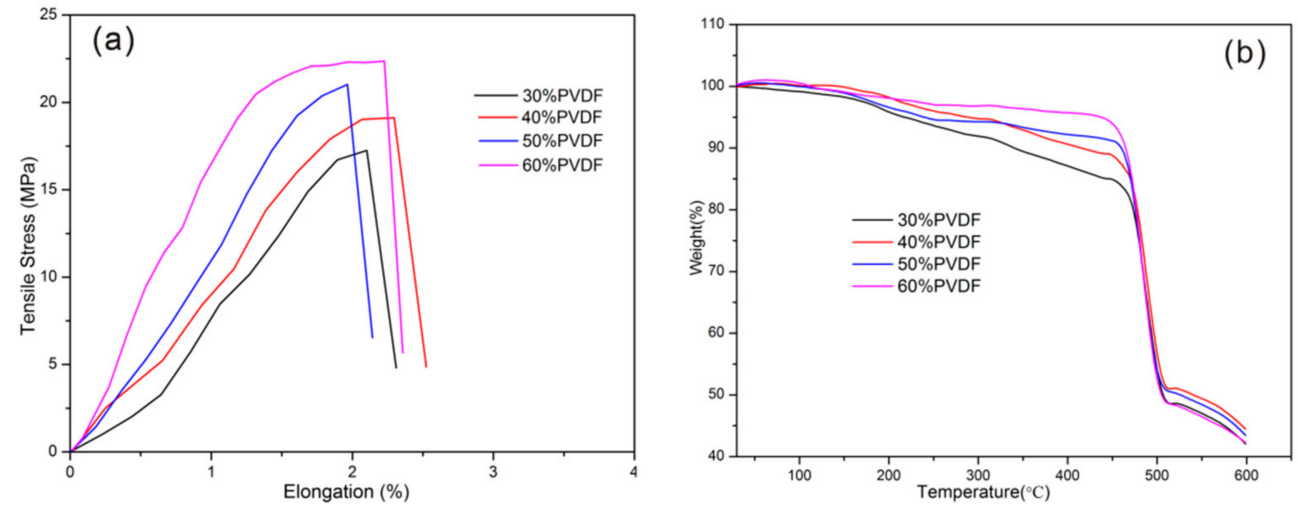

Figure 7. The stress-strain relationship (a) and the thermogravimetric (TG) curves (b) of the s-PI-PVDF composite membranes.

\section{Conclusions}

A hyper-branched sulfonated polyimide was designed and successfully synthesized as polymeric proton conductor. To prepare PEMs with high methanol-resistance and strong mechanical strength, PVDF was utilized as a binder to fabricate composite membranes with different content ratios. The detailed performances of these s-PI-PVDF composite membranes were measured by considering the requirements of DMFC application. The methanol permeability of these s-PI-PVDF composite membranes is revealed to be much higher than that of Nafion 117. All of the composite membranes also exhibit satisfied mechanical and thermal stabilities. With the good proton/methanol selectivity and great mechanical/thermal stabilities, the s-PI-PVDF composite membrane exhibited promising potential of application in DMFCs.

Author Contributions: Conceptualization, W.C., J.L. and L.M.; Methodology, W.C., J.L. and L.M.; Software, W.C.; Validation, W.C., J.L. and L.M.; Formal Analysis, L.M. and J.M.; Investigation, G.X., S.L., J.M.; Resources, W.C., J.L. and L.M.; Data Curation, W.C. and L.M.; Writing-Original Draft Preparation, L.M.; Writing-Review \& Editing, W.C.; Visualization, W.C. and J.L.; Supervision, W.C. and J.L.; Project Administration, W.C. and J.L.; Funding Acquisition, W.C., J.L. and L.M.

Acknowledgments: This work is supported by the National Natural Science Foundation of China (Nos. 21703211, 21875224 and 21503197), the Fundamental Research Funds of Guizhou Normal University (Nos.GZNUD [2017]1) and College Student Research Training Program of Guizhou Normal University (Nos.2017049).

Conflicts of Interest: The authors declare no conflict of interest.

\section{References}

1. Winter, M.; Brodd, R.J. What Are Batteries, Fuel Cells, and Supercapacitors? Chem. Rev. 2014, 104, 4245-4270. [CrossRef]

2. Yandrasits, M.A.; Hamrock, S.J. Membranes for PEM Fuel Cells: 3M Research Activites. In Fuel Cell Chemistry and Opration; Yandrasits, M.A., Zawodzinski, T.A., Jr., Hamrock, S.J., Eds.; ACS Publications: Washington, DC, USA, 2010; pp. 15-29.

3. Gubler, L. Polymer Design Strategies for Radiation-Grafted Fuel Cell Membranes. Adv. Energy Mater. 2014, 4, 1300827. [CrossRef]

4. Zhang, H.; Shen, P.K. Recent Development of Polymer Electrolyte Membranes for Fuel Cells. Chem. Rev. 2012, 112, 2780-2832. [CrossRef] [PubMed]

5. Vasileiadis, S.; Ziaka-Vasileiadou, Z. Efficient catalytic reactors-processors for fuel cells and synthesis applications. Sep. Purif. Technol. 2004, 34, 213-225. [CrossRef]

6. Vasileiadis, S.; Ziaka, Z. Small Scale Reforming Separation Systems with Nanomembrane Reactors for Direct Fuel Cell Applications. J. Nano Res. 2010, 12, 105-113. [CrossRef]

7. Zhou, X.; Weston, J.; Chalkova, E.; Hofmann, M.A.; Ambler, C.M.; Allcock, H.R.; Lvov, S.N. High temperature transport properties of polyphosphazene membranes for direct methanol fuel cells. Electrochim. Acta 2003, 48, 2173-2180. [CrossRef] 
8. Chen, Z.; Holmberg, B.; Li, W.; Wang, X.; Deng, W.; Munoz, R.; Yan, Y. Nafion/Zeolite Nanocomposite Membrane by in Situ Crystallization for a Direct Methanol Fuel Cell. Chem. Mater. 2006, 18, 5669-5675. [CrossRef]

9. Kreuer, K.-D. Proton Conductivity: Materials and Applications. Chem. Mater. 1996, 8, 610-641. [CrossRef]

10. Heinzel, A.; Barragán, V.M. A review of the state-of-the-art of the methanol crossover in direct methanol fuel cells. J. Power Sources 1999, 84, 70-74. [CrossRef]

11. Savadogo, O. Emerging membranes for electrochemical systems: Part II. High temperature composite membranes for polymer electrolyte fuel cell (PEFC) applications. J. Power Sources 2004, 127, 135-161. [CrossRef]

12. Li, L.; Deng, B.; Ji, Y.; Yu, Y.; Xie, L.; Li, J.; Lu, X. A novel approach to prepare proton exchange membranes from fluoropolymer powder by pre-irradiation induced graft polymerization. J. Membr. Sci. 2010, 346, 113-120. [CrossRef]

13. Alkan Gürsel, S.; Gubler, L.; Gupta, B.; Scherer, G.G. Radiation Grafted Membranes. In Fuel Cells I; Scherer, G.G., Ed.; Springer: Berlin, Germany, 2008; pp. 157-217.

14. Nakabayashi, K.; Matsumoto, K.; Ueda, M. Synthesis and properties of sulfonated multiblock copoly(ether sulfone)s by a chain extender. J. Polym. Sci. Part A Polym. Chem. 2008, 46, 3947-3957. [CrossRef]

15. Kim, D.S.; Robertson, G.P.; Kim, Y.S.; Guiver, M.D. Copoly(arylene ether)s Containing Pendant Sulfonic Acid Groups as Proton Exchange Membranes + NRCC Publication No. 50899. Macromolecules 2009, 42, 957-963. [CrossRef]

16. Lee, M.; Park, J.K.; Lee, H.-S.; Lane, O.; Moore, R.B.; McGrath, J.E.; Baird, D.G. Effects of block length and solution-casting conditions on the final morphology and properties of disulfonated poly(arylene ether sulfone) multiblock copolymer films for proton exchange membranes. Polymer 2009, 50, 6129-6138. [CrossRef]

17. Wang, C.; Shin, D.W.; Lee, S.Y.; Kang, N.R.; Lee, Y.M.; Guiver, M.D. Poly(arylene ether sulfone) proton exchange membranes with flexible acid side chains. J. Membr. Sci. 2012, 405-406, 68-78. [CrossRef]

18. Devanathan, R. Recent developments in proton exchange membranes for fuel cells. Energy Environ. Sci. 2008, 1, 101-119. [CrossRef]

19. Ma, X.; Zhang, C.; Xiao, G.; Yan, D. Synthesis and properties of sulfonated poly(arylene ether phosphine oxide)s for proton exchange membranes. J. Power Sources 2009, 188, 57-63. [CrossRef]

20. Zhang, W.; Gogel, V.; Friedrich, K.A.; Kerres, J. Novel covalently cross-linked poly(etheretherketone) ionomer membranes. J. Power Sources 2006, 155, 3-12. [CrossRef]

21. Ding, J.; Chuy, C.; Holdcroft, S. Enhanced Conductivity in Morphologically Controlled Proton Exchange Membranes: Synthesis of Macromonomers by SFRP and Their Incorporation into Graft Polymers. Macromolecules 2002, 35, 1348-1355. [CrossRef]

22. Chikashige, Y.; Chikyu, Y.; Miyatake, K.; Watanabe, M. Poly(arylene ether) Ionomers Containing Sulfofluorenyl Groups for Fuel Cell Applications. Macromolecules 2005, 38, 7121-7126. [CrossRef]

23. Bai, Z.; Dang, T.D. Direct Synthesis of Fully Sulfonated Polyarylenethioether Sulfones as Proton-Conducting Polymers for Fuel Cells. Macromol. Rapid Commun. 2006, 27, 1271-1277. [CrossRef]

24. Staiti, P.; Lufrano, F.; Aricò, A.S.; Passalacqua, E.; Antonucci, V. Sulfonated polybenzimidazole membranes-Preparation and physico-chemical characterization. J. Membr. Sci. 2001, 188, 71-78. [CrossRef]

25. Genova-Dimitrova, P.; Baradie, B.; Foscallo, D.; Poinsignon, C.; Sanchez, J.Y. Ionomeric membranes for proton exchange membrane fuel cell (PEMFC): Pulfonated polysulfone associated with phosphatoantimonic acid. J. Membr. Sci. 2001, 185, 59-71. [CrossRef]

26. Seo, D.W.; Lim, Y.D.; Lee, S.H.; Hossain, M.A.; Islam, M.M.; Lee, H.C.; Jang, H.H.; Kim, W.G. Preparation and characterization of block copolymers containing multi-sulfonated unit for proton exchange membrane fuel cell. Electrochim. Acta 2012, 86, 352-359. [CrossRef]

27. Seo, D.-W.; Lim, Y.-D.; Lee, S.-H.; Jeong, Y.-G.; Hong, T.-W.; Kim, W.-G. Preparation and characterization of sulfonated amine-poly(ether sulfone)s for proton exchange membrane fuel cell. Int. J. Hydrogen Energy 2010, 35, 13088-13095. [CrossRef]

28. Jones, D.J.; Rozière, J. Recent advances in the functionalisation of polybenzimidazole and polyetherketone for fuel cell applications. J. Membr. Sci. 2001, 185, 41-58. [CrossRef]

29. Tan, N.; Chen, Y.; Xiao, G.; Yan, D. Synthesis and properties of sulfonated polybenzothiazoles with benzimidazole moieties as proton exchange membranes. J. Membr. Sci. 2010, 356, 70-77. [CrossRef] 
30. Carbone, A.; Pedicini, R.; Portale, G.; Longo, A.; D’Ilario, L.; Passalacqua, E. Sulphonated poly(ether ether ketone) membranes for fuel cell application: Thermal and structural characterisation. J. Power Sources 2006, 163, 18-26. [CrossRef]

31. Li, W.; Zhang, F.; Yi, S.; Huang, C.; Zhang, H.; Pan, M. Effects of casting solvent on microstructrue and ionic conductivity of anhydrous sulfonated poly(ether ether ketone)-inoic liquid composite membranes. Int. J. Hydrogen Energy 2012, 37, 748-754. [CrossRef]

32. Kreuer, K.D. On the development of proton conducting polymer membranes for hydrogen and methanol fuel cells. J. Membr. Sci. 2001, 185, 29-39. [CrossRef]

33. Ma, L.; Cai, W.; Li, J.; Fan, K.; Jiang, Y.; Ma, L.; Cheng, H. A high performance polyamide-based proton exchange membrane fabricated via construction of hierarchical proton conductive channels. J. Power Sources 2016, 302, 189-194. [CrossRef]

34. Li, J.; Cai, W.; Ma, L.; Zhang, Y.; Chen, Z.; Cheng, H. Towards neat methanol operation of direct methanol fuel cells: A novel self-assembled proton exchange membrane. Chem. Commun. 2015, 51, 6556-6559. [CrossRef] [PubMed]

35. Zhang, Y.; Ting, J.W.Y.; Rohan, R.; Cai, W.; Li, J.; Xu, G.; Chen, Z.; Lin, A.; Cheng, H. Fabrication of a proton exchange membrane via blended sulfonimide functionalized polyamide. J. Mater. Sci. 2014, 49, 3442-3450. [CrossRef]

36. Yu, M.; Wang, W.; Li, C.; Zhai, T.; Lu, X.; Tong, Y. Scalable self-growth of Ni@NiO core-shell electrode with ultrahigh capacitance and super-long cyclic stability for supercapacitors. NPG Asia Mater. 2014, 6, e129. [CrossRef]

37. Zhang, Y.; Li, C.; Liu, X.; Yang, Z.; Dong, J.; Liu, Y.; Cai, W.; Cheng, H. Fabrication of a polymer electrolyte membrane with uneven side chains for enhancing proton conductivity. RSC Adv. 2016, 6, 79593-79601. [CrossRef]

38. Pang, J.; Zhang, H.; Li, X.; Liu, B.; Jiang, Z. Poly(arylene ether)s with pendant sulfoalkoxy groups prepared by direct copolymerization method for proton exchange membranes. J. Power Sources 2008, 184, 1-8. [CrossRef]

39. Xie, H.; Tao, D.; Xiang, X.; Ou, Y.; Bai, X.; Wang, L. Synthesis and properties of highly branched star-shaped sulfonated block poly(arylene ether)s as proton exchange membranes. J. Membr. Sci. 2015, 473, 226-236. [CrossRef]

40. Miyatake, K.; Zhou, H.; Watanabe, M. Proton Conductive Polyimide Electrolytes Containing Fluorenyl Groups: Synthesis, Properties, and Branching Effect. Macromolecules 2004, 37, 4956-4960. [CrossRef]

41. Yan, J.; Liu, C.; Wang, Z.; Xing, W.; Ding, M. Water resistant sulfonated polyimides based on 4,4'-binaphthyl-1,1', 8,8'-tetracarboxylic dianhydride (BNTDA) for proton exchange membranes. Polymer 2007, 48, 6210-6214. [CrossRef]

42. Wang, Y.; Xing, C.; Guan, J.; Li, Y. Towards Flexible Dielectric Materials with High Dielectric Constant and Low Loss: PVDF Nanocomposites with both Homogenously Dispersed CNTs and Ionic Liquids Nanodomains. Polymers 2017, 9, 562. [CrossRef]

43. Rana, D.; Mandal, B.M.; Bhattacharyya, S.N. Analogue Calorimetric Studies of Blends of Poly(vinyl ester)s and Polyacrylates. Macromolecules 1996, 29, 1579-1583. [CrossRef]

44. Rana, D.; Mandal, B.M.; Bhattacharyya, S.N. Analogue calorimetry of polymer blends: Poly(styrene-co-acrylonitrile) and poly(phenyl acrylate) or poly(vinyl benzoate). Polymer 1996, 37, 2439-2443. [CrossRef]

45. Rana, D.; Mandal, B.M.; Bhattacharyya, S.N. Miscibility and phase diagrams of poly(phenyl acrylate) and poly(styrene-co-acrylonitrile) blends. Polymer 1993, 34, 1454-1459. [CrossRef]

46. Lin, S.-C.; Burks, S.J. Compatible Polyvinylidene Fluoride Blends with Polymers Containing Imide Moieties. U.S. Patent 5959022A, 28 September 1999.

47. Zhang, Y.; Cai, W.; Si, F.; Ge, J.; Liang, L.; Liu, C.; Xing, W. A modified Nafion membrane with extremely low methanol permeability via surface coating of sulfonated organic silica. Chem. Commun. 2012, 48, 2870-2872. [CrossRef] [PubMed]

48. Karlsson, L.E.; Wesslén, B.; Jannasch, P. Water absorption and proton conductivity of sulfonated acrylamide copolymers. Electrochim. Acta 2002, 47, 3269-3275. [CrossRef]

49. Li, Q.; He, R.; Jensen, J.O.; Bjerrum, N.J. Approaches and recent development of polymer electrolyte membranes for fuel cells operating above 100 C. Chem. Mater. 2003, 15, 4896-4915. [CrossRef] 
50. Ansari, Y.; Tucker, T.G.; Huang, W.; Klein, I.S.; Lee, S.-Y.; Yarger, J.L.; Angell, C.A. A flexible all-inorganic fuel cell membrane with conductivity above Nafion, and durable operation at $150^{\circ} \mathrm{C}$. J. Power Sources 2016, 303, 142-149. [CrossRef]

51. Rana, D.; Sauvant, V.; Halary, J.L. Molecular analysis of yielding in pure and antiplasticized epoxy-amine thermosets. J. Mater. Sci. 2002, 37, 5267-5274. [CrossRef]

52. Rana, D.; Lee, C.H.; Cho, K.; Lee, B.H.; Choe, S. Thermal and mechanical properties for binary blends of metallocene polyethylene with conventional polyolefins. J. Appl. Polym. Sci. 1998, 69, 2441-2450. [CrossRef]

53. Rana, D.; Cho, K.; Woo, T.; Lee, B.H.; Choe, S. Blends of ethylene 1-octene copolymer synthesized by Ziegler-Natta and metallocene catalysts. I. Thermal and mechanical properties. J. Appl. Polym. Sci. 1999, 74, 1169-1177. [CrossRef]

54. Sasikala, S.; Meenakshi, S.; Bhat, S.D.; Sahu, A.K. Functionalized Bentonite clay-sPEEK based composite membranes for direct methanol fuel cells. Electrochim. Acta 2014, 135, 232-241. [CrossRef]

(C) 2018 by the authors. Licensee MDPI, Basel, Switzerland. This article is an open access article distributed under the terms and conditions of the Creative Commons Attribution (CC BY) license (http://creativecommons.org/licenses/by/4.0/). 